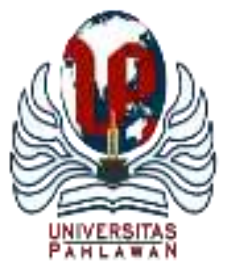

Edukatif : Jurnal Ilmu Pendidikan Volume 4 Nomor 1 Tahun 2022 Halm 298 - 307

EDUKATIF: JURNAL ILMU PENDIDIKAN

Research \& Learning in Education

https://edukatif.org/index.php/edukatif/index

\title{
Pengaruh Tingkat Pendidikan Terhadap Kinerja Pegawai dalam Melayani Masyarakat
}

\author{
Seri Hartati ${ }^{1 凶}$, Andhik Beni Saputra ${ }^{2}$, Sisi Andriani ${ }^{3}$
}

Program Studi Ilmu Pemerintahan, Universitas Abdurrab, Indonesia ${ }^{1,2,3}$

E-mail : seri.hartati@univrab.ac.id ${ }^{1}, \underline{\text { andhik.beni.s@univrab.ac.id }}^{2}, \underline{\text { andrianisisi448@gmail.com }}^{3}$

\begin{abstract}
Abstrak
Kinerja pelayanan publik menjadi hal yang penting dalam memberikan pelayanan kepada pengguna jasa. salah satu hal yang dapat mempengaruhi tingkat pendidikan pegawai sebagai sumber daya manusia. Penelitian ini mengungkapkan sejauh mana tingkat pendidikan (x) pegawai berpengaruh terhadap kinerja pegawai (y) dalam melayani masyarakat di kantor Kecamatan Kampar Kiri Hulu. Penelitian ini menggunakan pendekatan kuantitatif dengan menggunakan survei lapangan. 40 orang secara sukarela sebagai responden dengan tingkat respon $80 \%$. Hasil uji regresi yang diperoleh adalah tingkat pendidikan berpengaruh terhadap kinerja pegawai sebesar 38\%. Dalam penelitian ini juga digunakan beberapa variabel pemoderasi seperti pangkat atau jabatan pegawai, masa kerja, dan pengalaman pelatihan sehingga mempengaruhi hasil yang diperoleh.
\end{abstract}

Kata Kunci: tingkat pendidikan, kinerja pegawai, pelayanan publik

Abstract

The performance of public services in becoming an important thing in providing services to service users. one of the things that can influence the level of education of employees as human resources. This study reveals to what extent the education level $(x)$ of employees affects the performance of employees (y) in serving the community at the Kampar Kiri Hulu sub-district office. This study uses a quantitative approach by using a field survey. 40 people voluntarily as the respondents with a response rate of $80 \%$. The regression test results obtained are the level of education affects employee performance by 38\%. In this study also used several moderating variables such as rank or position of employees, years of service, and training experience so that they affect the results obtained.

Keywords: Education, Performance, Publik Service, Kampar

Copyright (c) 2022 Seri Hartati, Andhik Beni Saputra, Sisi Andriani

$\triangle$ Corresponding author

Email : seri.hartati@univrab.ac.id

DOI : https://doi.org/10.31004/edukatif.v4i1.1741

ISSN 2656-8063 (Media Cetak)

ISSN 2656-8071 (Media Online) 


\section{PENDAHULUAN}

Pendidikan mempunyai peranan yang sangat penting dalam meningkatkan kualitas sumber daya manusia (SDM), terutama pada era teknologi dan industri 4.0 saat ini (Hartati \& Arisandi, 2018). Pendidikan mempengaruhi kemajuan suatu bangsa, terutama bagi generasi muda (Murtasidin \& Hartati, 2017). Pendidikan mempunyai peran penting dalam aspek lingkungan kerja (Nugroho, 2014), karena pendidikan melatih pola berpikir dan pengembangan keterampilan yang sangat diperlukan oleh instansi pemerintahan ataupun swasta (Trisnawati, Syamsuadi, Hartati, \& Reskiyanti, 2021). Apabila organisasi ingin berkembang seyogyanya diikuti oleh pengembangan SDM (Widiansyah et al., 2018) melalui pendidikan (Ningrum, 2016) dan pelatihan (Suratman \& Eriyanti, 2020) yang berkesinambungan. Pendidikan dan pelatihan merupakan upaya untuk pengembangaan SDM (Sudarma, 2012). Pendidikan pada umumnya berkaitan dengan mempersiapkan calon tenaga yang digunakan oleh suatu organisasi (Nurhalita \& Hudaidah, 2021), sedangkan pelatihan lebih berkaitan dengan peningkatan kemampuan atau keterampilan pekerja yang sudah menduduki suatu jabatan atau tugas tertentu (Fikri, Asbari, Hutagalung, Amri, \& Novitasari, 2021).

Dalam kaitannya dengan pelayanan disebuah organisasi, sering sekali pelayanan publik menjadi sebuah indikator keberhasilan (Hartati, Syamsuadi, \& Arisandi, 2020). Kegiatan pelayanan publik telah diatur pemenuhannya berdasarkan regulasi yang dibuat oleh pemerintah pada Pasal 1 Ayat (1) Undang-Undang Nomor 25 Tahun 2009, dengan tujuan utamanya untuk memenuhi kebutuhan dasar dan kesejahteraan masyarakat. Dalam hal ini untuk melihat keberhasilan sebuah pelayanan didasarkan kepada standar pelayanan (Setyobudi, 2013). Standar pelayanan merupakan tolak ukur yang dipergunakan sebagai pedoman penyelenggaraan pelayanan dan acuan penilaian kualitas pelayanan sebagai kewajiban dan janji penyelenggara kepada masyarakat dalam rangka pelayanan yang berkualitas, cepat, mudah, terjangkau, dan teratur (Ahdhan, 2014).

Beberapa penelitian terdahulu yang berkaitan dengan penelitian ini diantaranya penelitian yang dilakukan oleh I Ketut Dartha. Penelitian ini bertujuan untuk mengetahui pengaruh secara simultan variabel pendidikan dan pelatihan dalam bentuk metode yang digunakan dan untuk mengetahui variabel mana dari pendidikan dan latihan yang berpengaruh paling dominan terhadap kinerja pegawai Sekretariat Daerah Kota Malang menggunakan metode Proportional Strafied Random Sampling. Hasil analisa data menunjukkan bahwa variabel pendidikan dan pelatihan berpengaruh secara signifikan baik secara simultan dan parsial terhadap kinerja pegawai Sekretariat Daerah Kota Malang, dan variabel materi diklat merupakan variabel yang paling dominan (Dartha, 2010).

Penelitian kedua yaitu oleh Hastin dan Jaya. Permasalahan yang diangkat adalah apakah ada pengaruh tingkat pendidikan pegawai terhadap kinerja pegawai Kantor Camat Gunung Tujuh, dan seberapa besar pengaruh tingkat pendidikan pegawai terhadap kinerja pegawai Kantor Camat Gunung Tujuh Kabupaten Kerinci. Tujuannya adalah untuk mengetahui pengaruh tingkat pendidikan pegawai terhadap kinerja pegawai Kantor Camat Gunung Tujuh. Jenis penelitian yang digunakan adalah deskriptif kuantitatif. Hasil penelitian mengatakan bahwa terdapat pengaruh yang positif dan signifikan antara pendidikan terhadap kinerja pegawai Kantor Camat Gunung Tujuh. Sedangkan dari perhitungan koefisien determinasi diperoleh makna bahwa faktor pendidikan memberikan kontribusi sebesar $84,64 \%$ terhadap kinerja pegawai Kantor Camat Gunung Tujuh (Hastin \& Jaya, 2014).

Penelitian ketiga oleh Hendriani dkk. pada studi kasus Bank Riau Kepri kantor pusat Pekanbaru. Tujuan penelitian ini adalah untuk menganalisis pengaruh pendidikan dan pelatihan terhadap kinerja, pengaruh kompetensi terhadap kinerja, dan pengaruh pendidikan dan pelatihan terhadap kompetensi, serta pengaruh pendidikan dan pelatihan terhadap kinerja yang dimediasi oleh kompetensi. Penelitian ini dilakukan di Bank Riau Kepri Cabang Kantor Pusat Pekanbaru dengan sampel penelitian sebanyak 65 petugas. Analisis Jalur digunakan untuk menganalisis data penelitian. Hasil penelitian menunjukkan bahwa variabel pendidikan dan 
300 Pengaruh Tingkat Pendidikan Terhadap Kinerja Pegawai dalam Melayani Masyarakat - Seri Hartati, Andhik Beni Saputra, Sisi Andriani

DOI: https://doi.org/10.31004/edukatif.v4i1.1741

pelatihan berpengaruh signifikan 0,379 terhadap kinerja, variabel kompetensi berpengaruh signifikan 0,385 terhadap kinerja, variabel pendidikan dan pelatihan berpengaruh signifikan 0,397 terhadap kompetensi, dan variabel pendidikan berpengaruh signifikan sebesar 0,535 terhadap kinerja yang dimediasi oleh kompetensi (Hendriani, Yulia, \& Fitriani, 2013).

Penelitian keempat oleh Wardono, penelitian yang dilakukan untuk melihat sejauh mana pengaruh pendidikan pelatihan dan motivasi kerja terhadap kinerja pegawai di Kantor Kecamatan Semen Kabupaten Kediri, dan Faktor manakah diantara pendidikan pelatihan dan motivasi kerja yang dominan pengaruhnya terhadap kinerja pegawai di Kantor Kecamatan Semen Kabupaten Kediri. Hasil penelitian menunjukkan bahwa adanya pengaruh dan hubungan yang signifikan antara variabel pendidikan pelatihan dan motivasi secara bersama-sama terhadap kinerja pegawai. Dari temuan ini dapat diketahui bahwa kontribusi teori yang ada sangat kecil pada model yang diuji. Hal ini menunjukkan masih ada variabel lain yang berpengaruh secara tidak langsung terhadap kinerja pegawai. Pendidikan pelatihan dan motivasi keduanya mempunyai pengaruh yang signifikan terhadap kinerja pegawai sebesar 63\%. Hasil empirik menunjukkan bahwa pemberian pendidikan pelatihan kepada pegawai mempunyai pengaruh yang lebih dominan terhadap kinerja pegawai.

Penelitian kelima oleh Budiantono yang bertujuan mengetahui secara parsial maupun simultan pengaruh pendidikan dan pengalaman kerja terhadap kinerja pegawai negeri sipil. Populasi dalam penelitian ini diambil dari jumlah pegawai tahun 2016 adalah sebanyak 158 pegawai, dan yang menjadi sampel sebanyak 61 pegawai. Teknik pengolahan data menggunakan regresi linier berganda. Hasilnya menunjukkan bahwa $\mathrm{R}$ square bernilai sebesar $54,1 \%$ dan sisanya dipengaruhi oleh variabel lain yang tidak diikutkan oleh penelitian ini. Setiap variabel berpengaruh positif dan signifikan terhadap kinerja pegawai negeri sipil.

Adapun rumusan masalah dalam penelitian ini adalah untuk mengetahui bagaimana pengaruh tingkat pendidikan terhadap kinerja pegawai dalam melayani masyarakat pada Kantor Camat Kampar Kiri Hulu. Diharapkan dengan penelitian ini akan mengungkapkan seberapa besar presentase pengaruh tingkat pendidikan $(\mathrm{X})$ terhadap kinerja pelayanan $(\mathrm{Y})$.

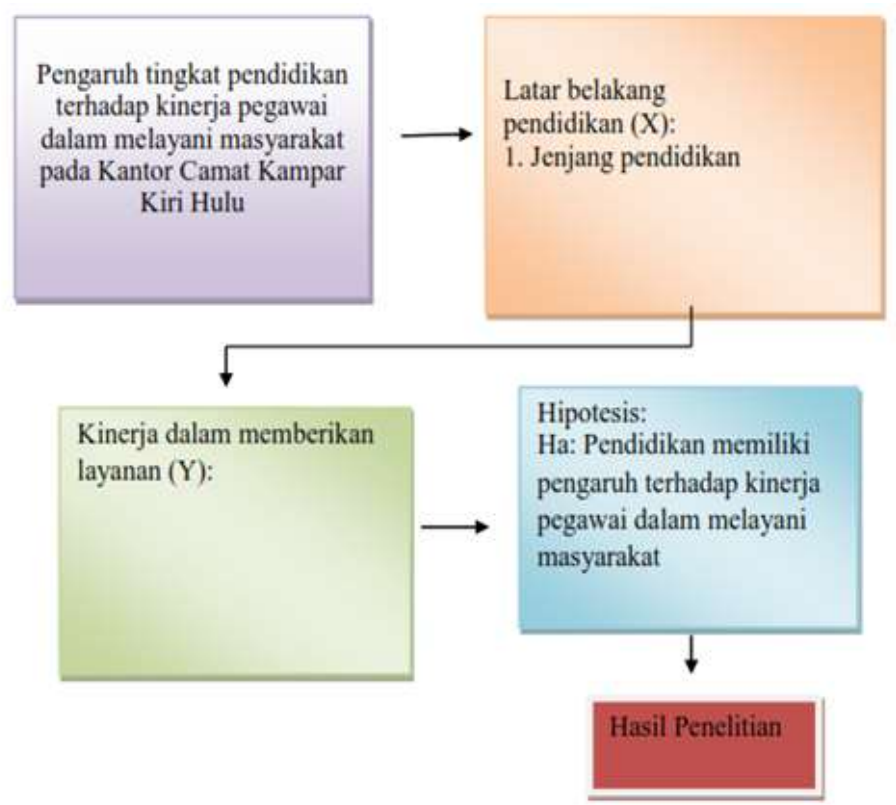

Gambar 1. Kerangka Penelitian 
301 Pengaruh Tingkat Pendidikan Terhadap Kinerja Pegawai dalam Melayani Masyarakat - Seri Hartati, Andhik Beni Saputra, Sisi Andriani

DOI: https://doi.org/10.31004/edukatif.v4i1.1741

Konsep new public service mempunyai model yang bisa dibedakan dengan konsep lainnya, seperti yang dikatakan Denhardt \& Denhardt (Alamsyah, 2016) bahwa prinsip-prinsipnya adalah:

a. Membantu warga masyarakat mengartikulasikan dan memenuhi kepentingan yang telah disepakati bersama daripada mencoba mengontrol atau mengendalian masyarakat kearah yang baru

b. Administrasi publik harus menciptakan gagasan kolektif yang disetujui bersama tentang apa yang disebut dengan kepentingan publik.

c. Kebijakan dan program yang ditujukan untuk memenuhi kebutuhan publik dapat dicapai secara efektif dan responsive melalui upaya-upaya koletif dan proses kolaboratif

d. Kepentingan publik lebih merupakan hasil suatu dialog tentang nilai-nilai yang disetujui bersama pada agregasi kepentingan pribadi para individu

e. Para pelayan publik harus memberikan perhatian, tidak semata pada pasar tetapi juga pada aspek hukum dan peraturan perundangan, nilai-nilai masyarakat, norma-norma politik standard profesional dan kepentingan warga masyarakat

f. Organisasi publik dan jaringan-jaringan yang terlibat akan sukses dalam jangka panjang kalau mereka beroperasi melalui proses kolaborasi atau melalui kepemimpinan yang menghargai semua orang

g. Kepentingan publik lebih baik dikembangkan oleh pelayan-pelayan publik dan warga masyarakat yang berkomitmen memberikan konstribusi terhadap masyarakat daripada oleh manajer wirausaha yang bertindak seakan-akan uang adalah milk mereka.

Pelajaran penting yang bisa diambil dari NPS ini adalah bahwa birokrasi harus dibangun agar dapat memberikan perhatian sebagai warganegara (bukan sebagai pelanggan), mengutamakan kepentingan umum (Usman, 2011), mengikutsertakan warga masyarakat (Fuady, 2012), berfikir strategis dan bertindak demokratis (Srihardjono \& Restyaningrum, 2017), memperhatikan norma, nilai dan standar yang ada dan menghargai masyarakat (Risnawan, 2021) dalam artian keterlibatan masyarakat menjadi sesuatu yang sangat penting.

\section{METODE PENELITIAN}

Penelitian ini dilaksanakan di Kecamatan Kampar Kiri Hulu yang merupakan salah satu kecamatan yang ada di Kabupaten Kampar Provinsi Riau. Dalam penelitian ini menggunakan pendekatan kuantitatif, karena pendekatan ini menggunakan perhitungan statistik dan menjelaskan fenomena yang dikaji peneliti. Penelitian ini bermaksud untuk menjelaskan suatu generalisasi sampel terhadap populasinya atau menjelaskan pengaruh satu variabel dengan variabel lainnya. penelitian ini menggunakan survei lapangan menggunakan kuisioner.

Dengan menggunakan kuisener peneliti mendapatkan data yang akurat melalui dua variabel yaitu variabel terikat yaitu kinerja pegawai dan variabel bebas adalah tingkat pendidikan. Adapun hipotesis penelitian ini adalah terdapat pengaruh signifikan tingkat pendidikan terhadap kinerja pegawai dalam melayani masyarakat di Kantor Kecamatan Kampar Kiri Hulu. Berdasarkan data dari daftar pegawai Kantor Camat Kampar Kiri Hulu, maka besar populasi pada penelitian ini adalah 40 orang. Jumlah populasi sebesar 40 orang ini kemudian penulis tetapkan sebagai sampel dan dilakukan survei. Pada penelitian ini, dari 40 responden yang ada terdapat 32 orang yang mengisi kuisioner yang diberikan penulis sehingga didapatkan response rate sebesar $80 \%$. Adapun yang menjadi indikator kinerja penelitian ini dapat dilihat pada tabel 1: 
302 Pengaruh Tingkat Pendidikan Terhadap Kinerja Pegawai dalam Melayani Masyarakat - Seri Hartati, Andhik Beni Saputra, Sisi Andriani

DOI: https://doi.org/10.31004/edukatif.v4i1.1741

Tabel 1. Indikator Penelitian

\begin{tabular}{llll}
\hline \multicolumn{1}{c}{ Fenomena } & \multicolumn{1}{c}{ Variable } & \multicolumn{1}{c}{ Landasan Teori } & \multicolumn{1}{c}{ Indikator } \\
\hline $\begin{array}{l}\text { Pengaruh tingkat } \\
\text { pendidikan terhadap }\end{array}$ & Tingkat & Pendidikan & Tingkat pendidikan \\
kinerja pegawai & Kendidikan $(\mathrm{X})$ & & \\
\cline { 2 - 4 } dalam melayani & pelayanan (Y) & a. New Public Service & a. Tangibles \\
masyarakat pada & & b. Kualitas layanan & b. Reliability \\
Kantor Camat & & & c. Responsivitas \\
Kampar Kiri Hulu & & & d. Assurance \\
\hline
\end{tabular}

\section{HASIL DAN PEMBAHASAN PENELITIAN}

Kampar Kiri Hulu merupakan kecamatan yang jaraknya sangat jauh dari Ibukota Kabupaten Kampar yaitu kota Bangkinang. Secara administratif Kampar kiri hulu dipimpin oleh Camat dan wakilnya. Dalam melaksanakan tugas pemerintahan, Camat Kampar kiri hulu dibantu oleh pegawainya dalam memberikan pelayanan kepada masyarakat Kampar kiri hulu. Jumlah penduduk kecamatan Kampar Kiri Hulu adalah 11.876 jiwa selama tahun 2015-2020 menunjukan peningkatan jumlah dari populasinya. Kecamatan Kampar kiri memiliki masyarakat dengan mata pencaharian beragam.

Adapun penelitian ini di laksanakan di kantor Kecamatan Kampar kiri dengan 40 responden, dari seluruh responden setelah dilakukan penyebaran kuisener dapat digambarkan hasil sebagai berikut:

\section{a. Tingkat Pendikan}

Secara keseluruhan jumlah responden dalam penelitian ini berdasarkan jenjang pendidikan sebagai berikut, responden yang berpendidikan SMP/Sederajat sebanyak (3\%), SMA/Sederajat sebanyak (65\%), selanjutnya yang berpendidikan S1 sebanyak (28\%), Magister/Mahasiswa S3 sebanyak (3\%). Untuk lebih lengkapnya dapat dilihat pada tabel dan grafik dibawah ini.

Tabel 2. Tingkat Pendidikan Responden

\begin{tabular}{|c|c|c|c|c|c|}
\hline & & Frequency & Percent & $\begin{array}{l}\text { Valid } \\
\text { Percent }\end{array}$ & $\begin{array}{l}\text { Cumulative } \\
\text { Percent }\end{array}$ \\
\hline \multirow[t]{5}{*}{ Valid } & SMP/Sederajat & 1 & 3.1 & 3.1 & 3.1 \\
\hline & SMA/Sederajat & 21 & 65.6 & 65.6 & 68.8 \\
\hline & S1 & 9 & 28.1 & 28.1 & 96.9 \\
\hline & Magister/Mahasiswa S2 & 1 & 3.1 & 3.1 & 100.0 \\
\hline & Total & 32 & 100.0 & 100.0 & \\
\hline
\end{tabular}

Masa kerja juga dikaitkan dengan tingkat pendidikan dalam penelitian ini dengan Masa kerja kurang dari 1 tahun sebanyak 3\%, 1-3 tahun sebanyak 31\%, 4-6 tahun sebanyak 44\%, 7-10 tahun sebanyak 16\%, dan lebih dari10 tahun sebanyak $6 \%$.

\section{b. Kinerja Pegawai dalam memberikan pelayanan}

1. ASN harus bisa menggunakan komputer

2. ASN harus melayani masyarakat secara professional

3. ASN harus memilki target konkret yang berorientasi pemberian pelayanan secara maksimal dan tepat waktu kepada masyarakat

4. ASN harus fokus melaksanakan pekerjaan yang telah menjadi tugas dan fungsi pokoknya

5. Kenaikan jabatan dan pemberian penghargaan kepada ASN harus berdasarkan pada capaian prestasi kerja yang telah dilakukannya 
303 Pengaruh Tingkat Pendidikan Terhadap Kinerja Pegawai dalam Melayani Masyarakat - Seri Hartati, Andhik Beni Saputra, Sisi Andriani

DOI: https://doi.org/10.31004/edukatif.v4i1.1741

6. ASN harus disiplin dalam mengikuti jam kerja yang telah ditetapkan oleh pimpinan

7. Penggunaan komputer mempermudah kerja ASN dalam melayani masyarakat

8. Peggunaan komputer membuat pelayanan publik menjadi lebih efektif dan efisien

9. Kemajuan teknologi informasi menjadikan prosedur pelayanan publik lebih singkat (simple) dan mudah

10.Mengikuti Pelatihan Pegawai Pemerintahan

11.Jenis Diklat yang pernah diikuti

c. Kualitas Pelayanan Publik pada Kantor Camat Kampar Kiri Hulu

1. Prosedur pelayanan yang diberikan oleh kantor dinas ini sangat mudah

2. Petugas harus melayani keperluan secara teliti dan meminimalisir kesalahan sekecil mungkin

3. Petugas memiliki tanggung jawab yang tinggi atas kesalahan dalam memberikan pelayanan

4. Petugas harus menyelesaikan keperluan dan urusan masyarakat secara tepat waktu

5. Petugas harus bersikap sopan santun dan sangat menghargai para pengunjung

6. Petugas harus memberikan pelayanan secara adil kepada pengunjung dan tidak membedakan suku, agama, dan ras.

Penelitian ini berupaya untuk menjelaskan pengaruh pendidikan yang penulis tetapkan sebagai variabel independen terhadap kinerja pegawai pada kantor camat Kampar Kiri Hulu yang bertindak sebagai variabel dependen. Berikut ini adalah hasil analisis data penelitian penulis.

Tabel 3. Variabel Penelitian

\begin{tabular}{lccl} 
& Variables & Variables & \\
\cline { 1 - 2 } Model & Entered & Removed & Method \\
\hline 1 & Pendidikan $^{\mathrm{b}}$ & & . Enter \\
\hline
\end{tabular}

a. Dependent Variable: Kinerja Pegawai di Kantor Camat Kampar Kiri Hulu

b. All requested variables entered

Tabel dibawah menampilkan nilai $\mathrm{R}$ yang merupakan simbol dari nilai koefisien korelasi. Pada tabel tersebut, nilai korelasi adalah 0.622. Nilai ini dapat diinterpretasikan bahwa hubungan kedua variabel penelitian ada di kategori cukup kuat. Nilai R Square 0.387 digenapkan menjadi Nilai R Square sama dengan $38 \%$ dapat ditafsirkan bahwa variablel Pendidikan memiliki pengaruh kontribusi sebesar 38\% terhadap variabel Kinerja Pegawai di Kantor.

Tabel 4. Koefisien Korelasi

\begin{tabular}{lllll}
\hline \multicolumn{1}{c}{ Model } & $\mathrm{R}$ & R Square & Adjuste R Square & Std. Error of the \\
\hline & $.622^{\mathrm{a}}$ & .387 & .367 & 3.679 \\
\hline & & & \\
\hline \\
a. Predictors: (Constant), Pendidikan \\
b. Dependent Variable: Kinerja Pegawai di Kantor Camat Kampar Kiri Hulu
\end{tabular}


304 Pengaruh Tingkat Pendidikan Terhadap Kinerja Pegawai dalam Melayani Masyarakat - Seri Hartati, Andhik Beni Saputra, Sisi Andriani

DOI: https://doi.org/10.31004/edukatif.v4i1.1741

Tabel 4 diatas digunakan untu menentukan taraf signifikansi atau linieritas dari regresi. Tabel ini memberikan informasi tentang ada tidaknya pengaruh pendidikan terhadap kinerja pegawai pada kantor camat Kampar Kiri Hulu. Berdasarkan pada tabel diatas, hasil analisis data penulis memperoleh nilai Sig. $=0,000$ yang berarti $<0,05$ sebagai kriteria signifikan.

Tabel 5. Hubungan Antar Variabel

\begin{tabular}{lcccccc}
\hline \multicolumn{2}{c}{ Model } & Sum of Squares & Df & Mean Square & F & Sig. \\
\hline 1 & Regression & 256.793 & 1 & 256.793 & 18.971 & $.000^{\mathrm{b}}$ \\
\hline & Residual & 406.082 & 30 & 13.536 & & \\
\cline { 2 - 6 } & & & & & \\
Total & 662.875 & 31 & & & \\
\hline
\end{tabular}

a. Dependent Variable: Kinerja Pegawai di Kantor Camat Kampar Kiri Hulu

b. Predictors: (Constant), Pendidikan

Tabel 5 menginformasikan model persamaan regresi yang penulis dapatkan dengan koefisien konstanta dan koefisien variabel yang ada di kolom Unstandardized Coefficients B. Berdasarkan tabel ini diperoleh model persamaan regresi: $\mathrm{Y}=41.045+2.769 \mathrm{X} 1$. Lebih lanjut, tabel di atas juga memberikan informasi tentang persamaan regresi dan ada tidaknya pengaruh pendidikan terhadap kinerja pegawai diterima. Berdasarkan hasil pengolahan data SPSS, nilai signifikansi variabel pendidikan sebesar 0.000 . Karena nilai 0.000 lebih kecil dari probabilitas 0.005 maka Ha (Hipotesis alternative) diterima dimana terdapat pengaruh pendidikan terhadap Kinerja Pegawai pada Kantor Camat Kampar Kiri Hulu dan Ho ditolak. Gambaran penerimaan hipotesis selengkapnya dapat dilihat pada Gambar 1.

Tabel 6. Uji Hipotesis

\begin{tabular}{|c|c|c|c|c|c|c|}
\hline & & \multicolumn{2}{|c|}{ Unstandardized Coefficients } & $\begin{array}{r}\text { Standardized } \\
\text { Coefficients }\end{array}$ & \multirow[b]{2}{*}{$\mathrm{T}$} & \multirow[b]{2}{*}{ Sig. } \\
\hline Model & & B & Std. Error & Beta & & \\
\hline 1 & (Constant) & 41.045 & 1.791 & & 22.919 & .000 \\
\hline & Pendidikan & 2.769 & .636 & .622 & 4.356 & .000 \\
\hline
\end{tabular}

a. Dependent Variable: Kinerja Pegawai di Kantor Camat Kampar Kiri Hulu 


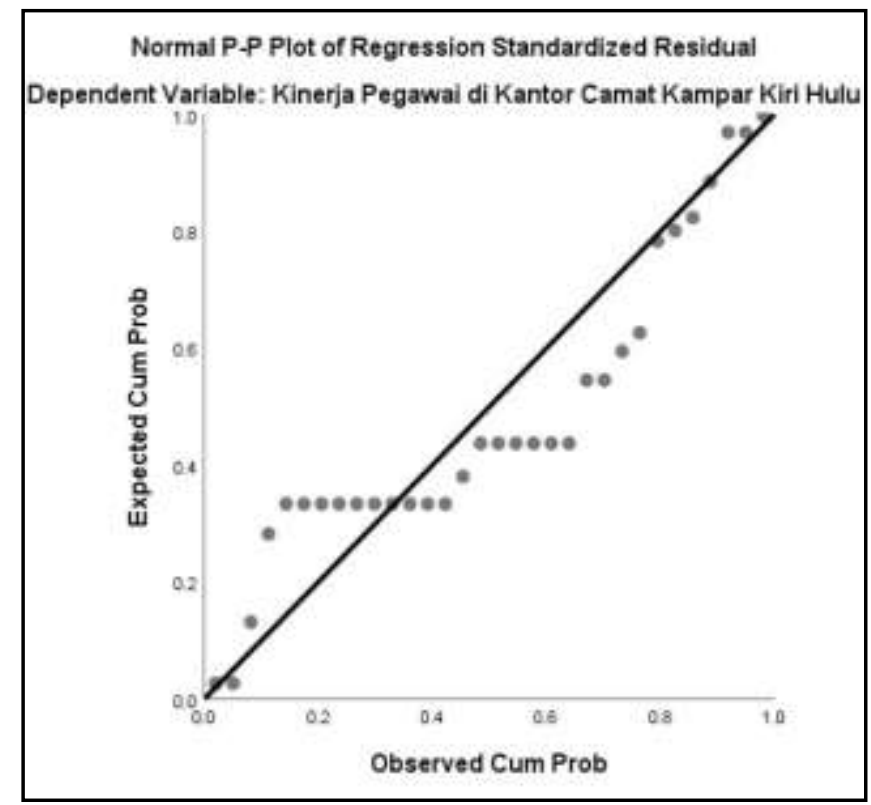

Gambar 2. Scatter Plot Uji Hipotesis

Berbeda dengan penelitian sebelumnya, penelitian ini menambahkan beberapa variabel moderator meliputi pangkat atau jabatan pegawai, masa kerja, dan pengalaman pelatihan. Dengan adanya variabel tambahan ini, hasil analisis yang diperoleh bisa dilihat dari sudut pandang yang berbeda. Dengan adanya perbedaan tersebut, hasil dari penelitian ini dapat memperkaya body of knowledge terkait analisis pengaruh tingkat pendidikan terhadap kinerja pegawai dalam hal pengembangan SDM.

Namun perlu diakui bahwa penelitian ini juga memiliki limitasi. Penelitian ini hanya terbatas hanya di Kecamatan Kampar Kiri Hulu saja, mengingat keterbatasan jangkauan peneliti. Selain itu, Variabel lainnya berupa kurang pemahaman dalam memanfaatkan teknologi, kurangnya sosialisi tentang pelayanan yang berbasis digital, serta tidak memiliki media internet dan lain-lain juga belum menjadi fokus penelitian ini.

\section{KESIMPULAN}

Berdasarkan hasil penelitian yang dilakukan oleh peneliti, terdapat pengaruh signifikan antara pendidikan terhadap kinerja pegawai pada Kantor Camat Kampar Kiri Hulu. Hal ini menunjukkan bahwa seiring berjalannya waktu apalagi saat ini para pegawai sangat dituntut untuk mampu beradaptasi dengan perilaku dan kebutuhan masyarakat yang cenderung menginginkan pelayanan yang efektif, efisien, transparansi serta menginginkan proses birokrasi yang mudah. Secara kuantitatif, penulis menetapkan pengaruh antara dua variabel yaitu variabel independen dan variabel dependen berada pada angka $38 \%$. Terdapat $62 \%$ yang berasal dari luar variabel lain yang turut mempengaruhi pendidikan terhadap kinerja pegawai pada Kantor Camat Kampar Kiri Hulu. Selain pengaruh variabel pendidikan, penulis menetapkan variabel tambahan sebagai moderator meliputi Pangkat, Masa Kerja, Pelatihan Pegawai untuk melihat apakah memiliki pengaruh terhadap kinerja pegawai pada Kantor Camat Kampar Kiri Hulu. Berdasarkan hasil uji analisis regresi linear penulis memperoleh hasil bahwa tidak terdapat pengaruh terhadap kinerja pegawai pada Kantor Camat Kampar Kiri Hulu. 
306 Pengaruh Tingkat Pendidikan Terhadap Kinerja Pegawai dalam Melayani Masyarakat - Seri Hartati, Andhik Beni Saputra, Sisi Andriani

DOI: https://doi.org/10.31004/edukatif.v4i1.1741

\section{DAFTAR PUSTAKA}

Ahdhan, R. D. (2014). Implementasi Undang-Undang Nomor 25 Tahun 2009 Tentang Pelayanan Publik Pada Dinas Kependudukan Dan Pencatatan Sipil Kabupaten Paser. Ejournal Ilmu Pemerintahan, Fisip Universitas Mulawarman, 2(2), 2185-2199.

Alamsyah, A. (2016). Perkembangan Paradigma Administrasi Publik (New Public Administration, New Public Management Dan New Public Service). Jurnal Publik Profetik, 04(2), 172-199.

Dartha, I. K. (2010). Pengaruh Pendidikan Dan Pelatihan (Diklat) Terhadap Kinerja Pegawai Negeri Sipil Pada Sekretariat Daerah Kota Malang. Jurnal Ekonomi Modernisasi, 6(2), 140-160.

Fikri, M. A. A., Asbari, M., Hutagalung, D., Amri, L. H. A., \& Novitasari, D. (2021). Quo Vadis Motivasi Intrinsik Pegawai: Peran Strategis Kepemimpinan Transformasional Dan Kepuasan Kerja. Edukatif: Jurnal Ilmu Pendidikan, 3(6), 4025-4040.

Fuady, A. H. (2012). Perencanaan Pembangunan Di Indonesia Pascaorde Baru: Refleksi Tentang Penguatan Partisipasi Masyarakat. Masyarakat Indonesia, 38(2), 375.

Hartati, S., \& Arisandi, D. (2018). Transformation Of Educational Organization Facing Industry 4.0 (Case Study Of Universitas Abdurrab). The 3rd International Seminar On Higher Education, 207-211. Retrieved From Https://Repository.Unri.Ac.Id/Handle/123456789/9710

Hartati, S., Syamsuadi, A., \& Arisandi, D. (2020). Kebijakan Publik: Refleksi Sektor Pendidikan. Taman Karya.

Hastin, M., \& Jaya, A. (2014). Pengaruh Pendidikan Terhadap Kinerja Pegawai Kantor Camat Gunung Tujuh Kabupaten Kerinci. Jurnal Penelitian Univrsitas Jambi Seri Humaniora, 16(September), 31-36.

Hendriani, S., Yulia, E., \& Fitriani, A. (2013). Pengaruh Pendidikan Dan Pelatihan Terhadap Kinerja Karyawan. Jurnal Administrasi Bisnis, 6(2), 1-8.

Murtasidin, B., \& Hartati, S. (2017). Demography Bonus And Policy Projection For Riau Province Youth Development. International Conference On Democracy, Accountability And Governance (Icodag 2017), 163(Icodag 2017), 216-219. Https://Doi.Org/10.2991/Icodag-17.2017.40

Ningrum, E. (2016). Pengembangan Sumber Daya Manusia Bidang Pendidikan. Jurnal Geografi Gea, 9(1). Https://Doi.Org/10.17509/Gea.V9i1.1681

Nugroho. (2014). Pengaruh Pendidikan Terhadap Pertumbuhan Ekonomi. Media Ekonomi Dan Manajemen, 29(2), 195-202.

Nurhalita, N., \& Hudaidah, H. (2021). Relevansi Pemikiran Pendidikan Ki Hajar Dewantara Pada Abad Ke 21. Edukatif: Jurnal Ilmu Pendidikan, 3(2), 298-303. Https://Doi.Org/10.31004/Edukatif.V3i2.299

Risnawan, W. (2021). Fungsi Birokrasi Dalam Efektivitas Pelayanan Publik. Dinamika : Jurnal Ilmiah Ilmu Administrasi Negara, 8(2), 156.

Setyobudi, Y. F. (2013). Peran Masyarakat Dalam Pelayanan Publik Sesuai Dengan Tentang Pelayanan Publik. Jurnal Dimensi, 2(1), 1-9.

Srihardjono, N. B., \& Restyaningrum, R. P. (2017). Reformasi Birokrasi Yang Terintegrasi Dalam New Public Service (Nps) Guna Mewujudkan Pemerintahan Yang Kuat Dan Bersih. Reformasi, 7(2), 69.

Sudarma, K. (2012). Mencapai Sumber Daya Manusia Unggul (Analisis Kinerja Dan Kualitas Pelayanan). Jurnal Dinamika Manajemen, 3(1), 76-83. Https://Doi.Org/10.15294/Jdm.V3i1.2462

Suratman, S., \& Eriyanti, E. (2020). Peningkatan Sumber Daya Manusia Melalui Pelatihan. Prosiding Seminar Nasional Pendidikan Program Pascasarjana Universitas Pgri Palembang, 599.

Trisnawati, L., Syamsuadi, A., Hartati, S., \& Reskiyanti, I. (2021). Koordinasi Pemerintah Dan Swasta Dalam Program Corporate Social Responsibility Improvement Di Kabupaten Pelalawan. Journal of Governance And Local Politics, 03(47), 115-123. 
307 Pengaruh Tingkat Pendidikan Terhadap Kinerja Pegawai dalam Melayani Masyarakat - Seri Hartati, Andhik Beni Saputra, Sisi Andriani

DOI: https://doi.org/10.31004/edukatif.v4i1.1741

Usman, J. (2011). Manajemen Birokrasi Profesional Dalam Meningkatkan Pelayanan Publik. Otoritas : Jurnal Ilmu Pemerintahan, 1(2). Https://Doi.Org/10.26618/Ojip.V1i2.24

Widiansyah, A., Sitasi, C., Widiansyah, :, Peranan, ), Daya, S., Sebagai, P., \& Penentu, F. (2018). Peranan Sumber Daya Pendidikan Sebagai Faktor Penentu Dalam Manajemen Sistem Pendidikan. Manajemen Sistem Pendidikan. Cakrawala, 18(2), 229-234. 